\title{
Detection Limits of Antimicrobials in Ewe Milk by Delvotest Photometric Measurements
}

\author{
R. L. Althaus, ${ }^{\star, 1}$ A. Torres, ${ }^{*}$ A. Montero, ${ }^{*}$ S. Balasch, $\dagger$ and M. P. Molina* \\ *Departamento de Ciencia Animal \\ †Departamento de Estadistica \\ Universidad Politécnica de Valencia \\ Camino de Vera, 14. Apartado 22012, (46071) Valencia, España
}

\begin{abstract}
The Delvotest method detection limits per manufacturer's instructions at a fixed reading time of $3 \mathrm{~h}$ for 24 antimicrobial agents were determined in ewe milk by photometric measurement. For each drug, eight concentrations were tested on 20 ewe milk samples from individual ewes. Detection limits, determined by means of logistic regression models, were ( $\mu \mathrm{g} / \mathrm{kg})$ : 3 , amoxycillin; 2, ampicillin; 18, cloxacillin; 1 , penicillin " $G$ "; 34, cefadroxil; 430, cephalosporin "C"; 40, cephalexin; 20, cefoperazone; 33, Ceftiofur; 18, cefuroxime; 6100 , streptomycin; 1200 , gentamycin; 2600 , neomycin; 830 , erythromycin; 100, tylosin; 180 , doxycycline; 320 , oxytetracycline; 590, tetracycline; 88 , sulfadiazine; 44 , sulfamethoxazole; 140 , sulfametoxypyridazine; 48 , sulfaquinoxaline; 12,000, chloramphenicol; and 290, trimethoprim. Whereas the beta-lactam antibiotics, sulphonamides, and tylosin were detected by Delvotest method at levels equal to those of maximum residue limits, its sensitivity needs to be enhanced to detect aminoglycosides, tetracyclines, streptomycin, chloramphenicol, and trimethoprim residues in ewe milk or to develop an integrated residue detection system for ewe milk with different sensitive microorganisms for each group of antiinfectious agents.
\end{abstract}

(Key words: ewe milk, microbial inhibitor test, detection limit, animicrobial)

Abbreviation key: EU = European Union, MRL = maximum residue limits.

\section{INTRODUCTION}

Antimicrobial agents are administered in therapeutic treatment of cattle and constitute a common cause of

Received April 26, 2002.

Accepted September 8, 2002.

Corresponding author: M. P. Molina; e-mail: pmolina@dca.upv.es.

${ }^{1}$ Current address: Departamento de Ciencias Básicas. Facultad de Ciencias Veterinarias. Universidad Nacional del Litoral. R.P.L. Kreder 2805. (3080) Esperanza, Argentina. the presence of chemotherapeutic drug residues in milk. Mastitis is the most prevalent disease of milk-producing cattle which requires antimicrobial treatment (Honkanen-Buzalski and Reybroeck, 1995).

The presence of certain antimicrobial agent residuals in milk constitutes a potential hazard for the consumer and may cause allergic reactions, interference in the intestinal flora, and resistant populations of bacteria in the general population, thereby rendering antibiotic treatment ineffective (Dewdney et al., 1991; Currie et al., 1998). Important losses are also provoked in the fermented products, by inhibiting the bacterial processes involved in the elaboration of cheese and cultured milk products (Mourot and Loussourorn, 1981; Brady and Katz, 1988).

For these reasons, several manufacturers have developed commercially available tests both for producers and the dairy industry with the aim of detecting drug residues in milk, among these the microbial inhibitor tests (IDF, 1991; Cullor, 1992).

The microbial inhibitor test procedure for detection of drug residues in milk is based on inhibition of spore outgrowth of organisms such as Bacillus stearothermophilus var. calidolactis (Carlsson and Björck, 1987), Bacillus cereus (Suhren and Heeschen, 1993), Bacillus subtilis (Aurelli et al., 1996), noted visually by interpreting the color change of a $\mathrm{pH}$-indicator present in the test medium.

Among the microbial inhibitor tests widely used for detection of veterinary medicines in cow milk, Delvotest "SP" is an economic, easy-to-use screening test giving results within a relatively short period (2.30 to 3.00 h). This method was recognized by the Association of Official Analytical Chemists (Katz, 1982; Kelley, 1982).

The Delvotest "SP" method is classified visually into three categories: "negative," "doubtful," and "positive," compared with the colors of "positive" and "negative" standard samples. The visual assessment is subjective, and the different modes of action of antimicrobial agents can influence the coloring of the indicator (Suhren and Luitz, 1995).

To avoid subjective differences in the visual interpretations and take the readings in an automated and 
more objective manner, some authors (Schiffmann, 1992; Luitz and Suhren, 1995; Luitz et al., 1996) propose performing photometric measurements utilizing an appropriate wavelength $(590 \mathrm{~nm})$ and another wavelength as reference $(650 \mathrm{~nm})$ in an ELISA reader.

Moreover, it must be emphasized that among the properties that should be considered in the evaluation of residual detection methods, the detection limit for each antimicrobial agent deserves special attention, with the aim of preventing milk with drug residuals in excess of Maximum Residue Limits (MRL) from being marketed and reaching the consumer.

The detection limits of Delvotest "SP" have been determined in cow milk by means of visual assessment in several works (Van Os and Beukers, 1980; Senyk et al., 1990; Luitz and Suhren, 1996; Luitz et al., 1996; Zaadhof et al., 1997), although only on very few occasions in the milk of other species such as ewe milk (Althaus, 1999).

Furthermore, no studies on Delvotest detection limits utilizing photometric measurements in any type of milk are present in the bibliography. For this reason, the aim of this research was to calculate the Delvotest "SP" detection limits for 24 antimicrobial agents in ewe milk by means of the relative absorption method.

\section{MATERIALS AND METHODS}

\section{Milk Samples}

Milk samples were collected from Manchega ewes of the experimental flock located on the farm of the Department of Animal Science, Valencia (Spain). The animals received no pharmacological treatment from the moment of lambing until termination of the whole lactation period.

For this study, milk samples corresponding to the morning machine milking session $(0800 \mathrm{~h})$ of 20 ewes were collected in the 60 to 90 -d period postpartum.

\section{Delvotest "SP" Microbial Test}

Milk samples were analyzed during the 6-hr period after collection by Delvotest "SP" (DSM Food Specialties, Dairy Ingredients, Delft, The Netherlands). The method was carried out according to the instructions of the manufacturer. Thus, $100-\mu \mathrm{l}$ milk samples were added to individual Delvotest cups ready prepared containing B. stearothermophilus var. calidolactis and indicator in solid medium. One nutrient tablet, containing carbon and nitrogen source facilitating growth/metabolism of the test organism, was added to each cup, and the plates were sealed with the tape supplied. Plates were incubated in a water bath at $64 \pm 1^{\circ} \mathrm{C}$ for $3 \mathrm{~h}$, following the manufacturer's instructions for ewe milk.
Immediately after the incubation period, absorbance was measured with the ELISA reader (Wallac 1420, Victor Multilavel Counter) using 590 and $650 \mathrm{~nm}$ as measuring and reference wavelengths, respectively. The optimum wavelength for measuring color change is $590 \mathrm{~nm}$ for the Delvotest bromoCresol Purple $\mathrm{pH}$ indicator system. The wavelength of $650 \mathrm{~nm}$ is taken as a reference wavelength to correct for cell-length differences (Luitz and Suhren, 1995). Dual readings (590 to $650 \mathrm{~nm}$ ) were used in the calculations.

In each microplate, the photometric measurements were expressed in relative absorbances, according to the following transformation:

$$
\mathrm{A}=\left(\mathrm{A}_{\mathrm{x}}-\mathrm{A}_{0}\right) /\left(\mathrm{A}_{100}-\mathrm{A}_{0}\right),
$$

where: $\mathrm{A}=$ relative absorbance, $\mathrm{A}_{\mathrm{x}}=$ milk sample absorbance with " $\mathrm{x}$ " antibiotic concentration, $\mathrm{A}_{0}=\mathrm{ab}$ sorbance of antibiotic free milk (negative control), $\mathrm{A}_{100}$ $=$ milk sample absorbance with the antibiotic concentration that produces $100 \%$ of positive results. The positive results (purple color) were assessed visually by two trained persons.

\section{Preparation of Antimicrobial Test Solutions}

Table 1 summarizes the antimicrobial agents and the concentrations used for the preparation of their solutions. These drugs were stored and handled according to the manufacturers' instructions before being used. All dilutions were prepared in 100-ml volumetric flasks at the day of analysis, in order to avoid possible inconvenience due to instability of the solutions.

The chemotherapeutic solutions were prepared in one step only from the respective stock solution using antimicrobial-free ewe milk as determined by the Delvotest "SP". Final concentrations of drugs in milk ( $\mu \mathrm{g} / \mathrm{kg})$ were achieved after serial dilutions, in such a way that the volume of the antimicrobial agent solution did not exceed $1 \%$ of the volume of the final solution to be analyzed (Reichmuth et al., 1997; IDF, 1999).

Detection limits of the antimicrobial agents were established in line with the IDF indications (IDF, 1999). To this end, eight concentrations were prepared with different levels of each drug. For each concentration, 20 replicates were prepared using antibiotic-free milk samples obtained from individual animals (160 analyses for antiinfectious agents).

\section{Statistical Analysis}

The results were achieved using SAS LOGISTIC procedure (SAS, 1998). The logistic regression for analyzing the effect of concentration of antimicrobial agents 
Table 1. Antimicrobial agent concentrations employed for Delvotest "SP" detection limits in ewe milk.

\begin{tabular}{|c|c|c|}
\hline Antimicrobial agents & Product number & Concentrations $(\mu \mathrm{g} / \mathrm{kg}$ or $* \mathrm{mg} / \mathrm{kg})$ \\
\hline \multicolumn{3}{|l|}{ Beta-lactam antibiotics } \\
\hline Amoxycillin & Sigma A-8523 & $0,1,2,3,4,5,6,8$ \\
\hline Ampicillin & Sigma A-9518 & $0,1,2,3,4,5,6,8$ \\
\hline Cloxacillin & Sigma C-9393 & $0,10,20,30,40,60,80,100$ \\
\hline Penicillin "G" & Sigma PEN-Na & $0,1,2,3,4,5,6,8$ \\
\hline Cefadroxil & Sigma C-7020 & $0,20,40,60,80,100,120,150$ \\
\hline Cephalosporin "C" & Sigma C-3270 & $0,100,200,300,400,500,800,1000$ \\
\hline Cephalexin & Sigma C-4895 & $0,20,40,60,80,100,120,150$ \\
\hline Cefoperazone & Sigma C-4292 & $0,10,20,30,40,60,80,100$ \\
\hline Ceftiofur ${ }^{\circledR}$ & Pharmacia $^{1}$ & $0,10,20,30,40,60,80,100$ \\
\hline Cefuroxime & Sigma C-4417 & $0,10,20,30,40,60,80,100$ \\
\hline \multicolumn{3}{|l|}{ Aminoglycosides } \\
\hline Streptomycin & Sigma S-6501 & $0,1,2,4,6,8,10,15^{*}$ \\
\hline Gentamycin & Sigma G-3632 & $0,0.25,0.50,0.75,1,2.5,5,10^{*}$ \\
\hline Neomycin & Sigma N-1876 & $0,0.25,0.50,0.75,1,2.5,5,10^{*}$ \\
\hline \multicolumn{3}{|l|}{ Macrolides } \\
\hline Erythromycin & Sigma E-6376 & $0,0.1,0.2,0.4,0.6,0.8,1,1.5^{*}$ \\
\hline Tylosin & Sigma T-6134 & $0,2.5,5,7.5,10,25,50,100$ \\
\hline \multicolumn{3}{|l|}{ Tetracyclines } \\
\hline Doxycycline & Sigma D-9891 & $0,100,200,300,400,600,800,1000$ \\
\hline Tetracycline & Sigma T-3258 & $0,100,200,300,400,600,800,1000$ \\
\hline Oxytetracycline & Sigma O-5750 & $0,100,200,300,400,600,800,1000$ \\
\hline \multicolumn{3}{|l|}{ Sulphonamides } \\
\hline Sulfadiazine & Sigma S-6387 & $0,50,100,200,300,400,500,800$ \\
\hline Sulfamethoxazole & Sigma S-7507 & $0,20,40,60,80,100,200,300$ \\
\hline Sulfametoxypyridazine & Sigma S-7257 & $0,50,100,200,300,400,600,800$ \\
\hline Sulfaquinoxaline & Sigma S-7382 & $0,50,100,200,300,400,500,800$ \\
\hline \multicolumn{3}{|l|}{ Other antimicrobials } \\
\hline Chloramphenicol & Sigma C-0378 & $0,5,10,20,30,40,60,80^{*}$ \\
\hline Trimethoprim & Sigma T-7883 & $0,0.25,0.50,0.75,1,2.5,5,10^{*}$ \\
\hline
\end{tabular}

aThe Upjohn Co., Kalamazoo, MI.

upon the relative absorption of Delvotest "SP" was the following:

$$
\mathrm{L}_{\mathrm{ij}}=\beta_{0}+\beta_{1} \mathrm{AC}_{\mathrm{i}}+\varepsilon_{\mathrm{ij}}
$$

where: $\mathrm{L}_{\mathrm{ij}}=$ logit variable (ln $\left.\mathrm{A}_{\mathrm{ij}} / 1-\mathrm{A}_{\mathrm{ij}}\right) ; \beta_{0}, \beta_{1}=$ coefficients estimated for logistic regression model; $\mathrm{AC}_{\mathrm{i}}=$ antimicrobial concentration; $\varepsilon_{\mathrm{ij}}=$ residual error.
The concordance coefficient (C) was applied as rank correlation between the observed and predicted relative absorption (SAS, 1998).

The detection limit of the photometric measurements of the Delvotest "SP" was calculated as the antimicrobial concentrations that produces $45 \%$ of the maximum relative absorption (Luitz and Suhren, 1995; Luitz et al., 1996).

Table 2. Summary of logistic regression model parameters and Delvotest "SP" detection limits ( $\mu \mathrm{g} / \mathrm{kg})$ of beta-lactam antibiotics in ewe milk.

\begin{tabular}{llllrr}
\hline Beta-lactam antibiotics & $\beta_{0}$ & $\beta_{1}$ & $\begin{array}{l}\text { Concordance } \\
\text { coefficients }\end{array}$ & $\begin{array}{l}\text { Detection } \\
\text { limits }\end{array}$ & MRL $^{1}$ \\
\hline Amoxycillin & -3.321 & 1.2020 & 90.6 & 3 & 4 \\
Ampicillin & -1.953 & 0.8894 & 87.0 & 2 & 4 \\
Cloxacillin & -1.698 & 0.0896 & 91.1 & 18 & 30 \\
Penicillin "G" & -1.256 & 1.2164 & 90.7 & 1 & 4 \\
Cefadroxil & -2.466 & 0.0701 & 92.5 & 34 & $\ldots$ \\
Cephalosporin "C" & -3.470 & 0.0078 & 86.7 & 430 & $\ldots$ \\
Cephalexin & -2.613 & 0.0629 & 93.4 & 20 & 50 \\
Cefoperazone & -2.054 & 0.1006 & 87.8 & 33 & 100 \\
Ceftiofur & -2.251 & 0.0656 & 82.7 & 18 & $\ldots$ \\
Cefuroxime & -2.994 & 0.1607 & 92.6 &
\end{tabular}

${ }^{1} \mathrm{MRL}(\mu \mathrm{g} / \mathrm{kg})=$ European Union maximum residue limits. 


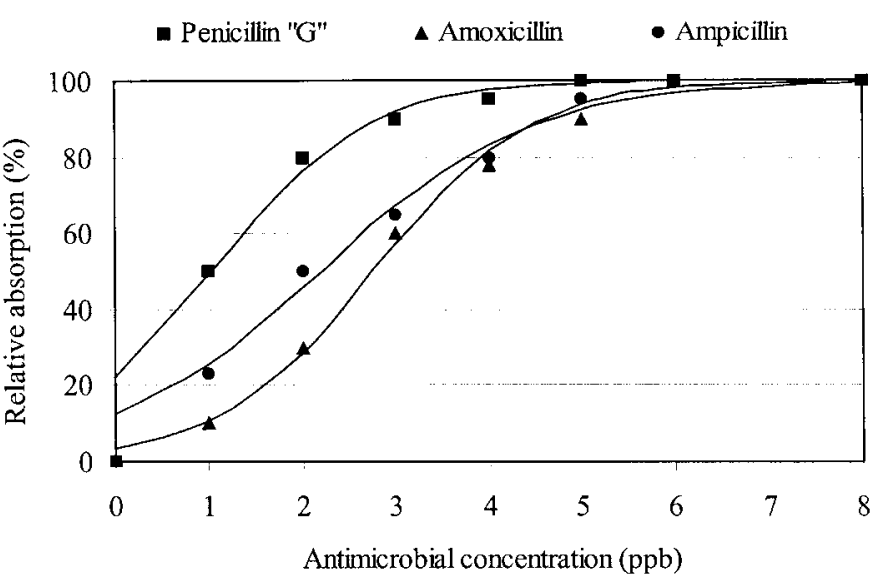

Figure 1. Relation between amoxycillin, ampicillin, and penicillin "G" concentration and relative absorption to the Delvotest "SP" in ewe milk. Each point represents the mean of 20 determinations.

\section{RESULTS AND DISCUSSION}

The results of the application of the logistic regression model to the relative absorption of Delvotest "SP" for the different beta-lactam antibiotics assayed are shown in Table 2. Also shown are the detection limits of Delvotest "SP" calculated by means of logistic model and the $45 \%$ relative absorbance approach (Luitz and Suhren, 1995; Luitz et al., 1996), along with the values of the MRL set out by the European Union (EU-MRL).

It may be observed that the concordant coefficients were high, falling between $82.7 \%$ for Ceftiofur and 93.4\% for cephalexin, illustrating the appropriate adjustment achieved by means of the logistic model.

Given the interpretation of the " $\beta_{1}$ " parameter of the model, the greater values of the same for penicillin " $G$," ampicillin and amoxycillin (Table 2) indicate a greater increase in relative absorbance with the concentration, i.e., a higher sensitivity in its detection than for the rest of the betalactamics assayed (cephalosporin "C," cephalexin, Ceftiofur, cefadroxil, and cloxacillin; Table 2).

Figures 1 and 2 show the effect of the concentrations of penicillins and other beta-lactam antibiotics on the Delvotest method relative absorption, as well as the curves constructed by means of the logistic model (" $\beta_{0}$ " and " $\beta_{1}$ " coefficients; Table 2 ). In these figures, each point represents the mean value of 20 determinations.

Ampicillin, amoxycillin, and penicillin "G," presenting high " $\beta_{1}$ " coefficient values, require small increments in their concentrations to produce $100 \%$ relative absorption ( $6 \mu \mathrm{g} / \mathrm{kg}$, Figure 1), whereas the beta-lactam antibiotics shown in Figure 2 presented lower " $\beta_{1}$ " coefficient values than the penicillin group, requiring greater increments in their concentrations in order to reach $100 \%$ absorbance (between 50 and $120 \mu \mathrm{g} / \mathrm{kg}$ ).

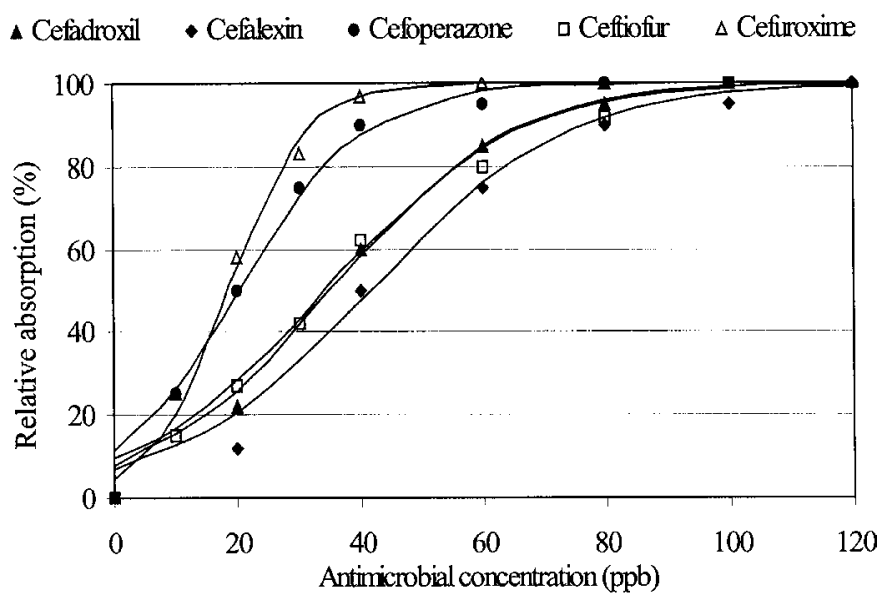

Figure 2. Relation between cefadroxil, cefalexin, cefoperazone, ceftiofur, and cefuroxime concentration and relative absorption to the Delvotest "SP" in ewe milk. Each point represents the mean of 20 determinations.

Table 3 summarizes the values of the statistical parameters, detection limits, and EU-MRL for sulphonamides. The effect of sulphonamide concentrations upon the relative absorbance of Delvotest "SP" is shown in Figure 3, where the logistic curves constructed on the basis of the " $\beta_{0}$ " and " $\beta_{1}$ " coefficient in Table 3 are also represented. It may be observed that sulfametoxypyridazine requires greater increments in concentration than the other sulphonamides assayed in order to achieve $100 \%$ absorbance.

The logistical parameters of the other antimicrobial agents (aminoglycosides, macrolides, tetracyclines, chloramphenicol, and trimethoprim) are shown in Table 4 . It may be seen that the " $\beta_{1}$ " coefficient values are lower than those obtained for beta-lactam antibiotics (Table 2). This demonstrates the low sensitivity of $B a$ cillus stearothermophilus in detecting residues of these antimicrobial agents compared with the beta-lactam antibiotics.

The Delvotest "SP" method detection limits found in the literature consulted were determined by means of visual readings in cow milk; thus, the results with said values for each of the antimicrobial groups studied are discussed below.

\section{Beta-Lactam Antibiotics}

The detection limit of amoxycillin ( $3 \mu \mathrm{g} / \mathrm{kg}$, Table 2$)$ was lower than the $6 \mu \mathrm{g} / \mathrm{kg}$ determined by HonkanenBuzalski and Reybroeck (1995) and Suhren and Reichmuth (1998). In the case of ampicillin, the level detected in this work ( $2 \mu \mathrm{g} / \mathrm{kg}$, Table 2$)$ was similar to the $3 \mu \mathrm{g} /$ $\mathrm{kg}$ calculated by Luitz et al. (1996), while the $18 \mu \mathrm{g} / \mathrm{kg}$ of cloxacillin (Table 2) was lower than the $30 \mu \mathrm{g} / \mathrm{kg}$ 
Table 3. Summary of logistic regression model parameters and Delvotest "SP" detection limits ( $\mu \mathrm{g} / \mathrm{kg}$ ) of sulphonamides in ewe milk.

\begin{tabular}{llllcc}
\hline Sulphonamides & $\beta_{0}$ & $\beta_{1}$ & $\begin{array}{l}\text { Concordance } \\
\text { coefficients }\end{array}$ & $\begin{array}{l}\text { Detection } \\
\text { limits }\end{array}$ & MRL $^{1}$ \\
\hline Sulfadiazine & -2.159 & 0.0236 & 93.3 & 88 & 100 \\
Sulfamethoxazole & -0.736 & 0.0146 & 82.9 & 44 & 100 \\
Sulfametoxypyridazine & -1.434 & 0.0095 & 85.7 & 140 & 100 \\
Sulfaquinoxaline & -0.846 & 0.0157 & 90.1 & 48 & 100 \\
\hline
\end{tabular}

${ }^{1} \mathrm{MRL}(\mu \mathrm{g} / \mathrm{kg})=$ European Union maximum residue limits.

detected by Van Os and Beukers (1980) and Gardner et al. (1996).

In the present study, penicillin " $G$ " presented a detection limit of $1 \mu \mathrm{g} / \mathrm{kg}$ (Table 2), lower than the values reported by Charm and Ruth (1993); Honkanen-Buzalski and Reybroeck (1995); Gardner et al. (1996) and Suhren and Reichmuth (1998), which ranged from 2.5 to $4 \mu \mathrm{g} / \mathrm{kg}$ of penicillin.

The fact that the detection limit of penicillin "G" calculated by means of photometric measurements in ewe milk were lower than those obtained by means of visual interpretation in cow milk by other authors could be attributed to the different approaches used in calculations.

Indeed, Althaus et al. (2001), utilizing the Brilliant Black Reduction Test (BRT), obtained lower values in the detection limits when calculated as the concentration producing $45 \%$ of the maximum relative absorption by photometric measurement than when calculating the detection limit as the concentration producing $95 \%$ of "positive results" by visual evaluation.

This makes it necessary to reconsider the calculation criteria for detection limits depending on whether photometric readings or visual evaluation are employed, in order to obtain similar values in both cases.
On the other hand, Ceftiofur also presented a detection limit (33 $\mu \mathrm{g} / \mathrm{kg}$, Table 2) in ewe milk lower than the $50 \mu \mathrm{g} / \mathrm{kg}$ obtained by other authors (Charm and Ruth, 1993; Honkanen-Buzalski and Reybroeck, 1995; and Gardner et al., 1996).

It must be emphasized that the detection limits calculated by photometric measurements for ampicillin, amoxycillin, penicillin " $G$," cephalexin, cefoperazone, and Ceftiofur were lower than the EU-MRL (Table 2). No detection limit values for cefadroxil, cephalosporin "C", cephalexin, cefoperazone and cefuroxime in milk of any other species were found in the consulted literature.

\section{Sulphonamides}

The detection limits for sulphonamides calculated by photometric measurements (Figure 3) were similar to EU-MRL (100 $\mu \mathrm{g} / \mathrm{kg}$, Table 3). It should be noted that the sulfadiazine detection limit ( $88 \mu \mathrm{g} / \mathrm{kg}$ ) in ewe milk was lower than the $1000 \mu \mathrm{g} / \mathrm{kg}$ reported by Charm and Ruth (1993) with cow milk samples. In the literature consulted, no detection limits were found for sulfamethoxazole, sulfametoxypyridazine, and sulfaquinoxaline in milk of any other species.

Table 4. Summary of logistic regression model parameters and Delvotest "SP" detection limits ( $\mu \mathrm{g} / \mathrm{kg}$ ) of aminoglycosides, macrolides, tetracyclines, chloramphenicol, and trimethoprim in ewe milk.

\begin{tabular}{|c|c|c|c|c|c|}
\hline Antimicrobial agents & $\beta_{0}$ & $\beta_{1}$ & $\begin{array}{l}\text { Concordance } \\
\text { coefficients }\end{array}$ & $\begin{array}{l}\text { Detection } \\
\text { limits }\end{array}$ & $\mathrm{MRL}^{1}$ \\
\hline \multicolumn{6}{|l|}{ Aminoglycosides } \\
\hline Streptomycin & -3.155 & 0.0005 & 86.8 & 6100 & 200 \\
\hline Gentamycin & -1.576 & 0.0012 & 88.5 & 1200 & 100 \\
\hline Neomycin & -1.877 & 0.0007 & 83.2 & 2600 & 500 \\
\hline \multicolumn{6}{|l|}{ Macrolides } \\
\hline Erythromycin & -4.160 & 0.0049 & 87.4 & 830 & 40 \\
\hline Tylosin & -2.438 & 0.0232 & 91.1 & 100 & 50 \\
\hline \multicolumn{6}{|l|}{ Tetracyclines } \\
\hline Doxycycline & -3.354 & 0.0181 & 86.8 & 180 & \\
\hline Oxytetracycline & -2.023 & 0.0059 & 88.4 & 320 & 100 \\
\hline Tetracycline & -2.881 & 0.0047 & 86.7 & 590 & 100 \\
\hline \multicolumn{6}{|c|}{ Other chemotherapeutics } \\
\hline Chloramphenicol & -2.529 & 0.0002 & 94.8 & 12,000 & 0 \\
\hline Trimethoprim & -0.380 & 0.0010 & 85.3 & 290 & 50 \\
\hline
\end{tabular}

${ }^{1} \mathrm{MRL}(\mu \mathrm{g} / \mathrm{kg})$, European Union maximum residue limits. 


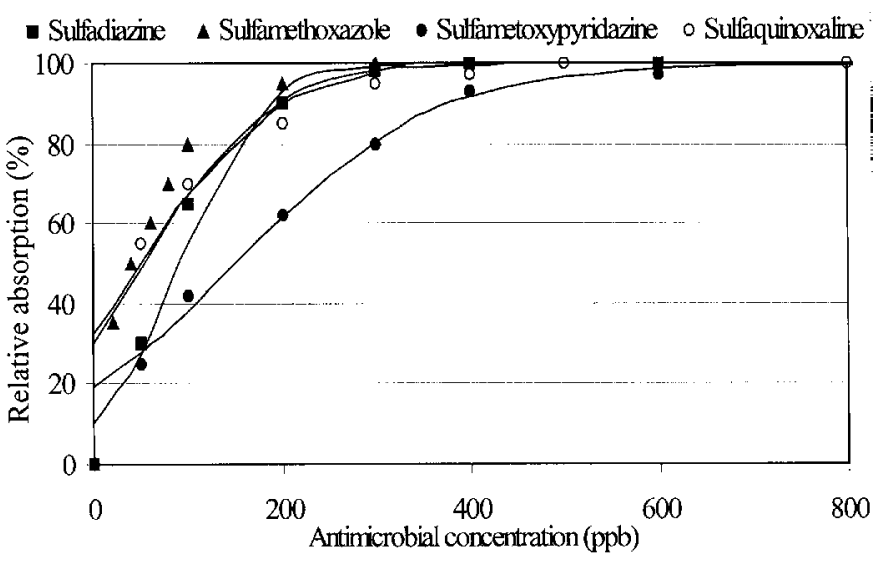

Figure 3. Relation between sulfadiazine, sulfamethoxazole, sulfametoxypyridazine and sulfaquinoxaline concentration and relative absorption to the Delvotest "SP" in ewe milk. Each point represents the mean of 20 determinations.

\section{Aminoglycosides}

Table 4 shows the detection limits for aminoglycosides. Detection limits calculated by photometric measurements in ewe milk were 6100 (streptomycin) and $1200 \mu \mathrm{g} / \mathrm{kg}$ (gentamycin). Said values were similar to the $6000 \mu \mathrm{g} / \mathrm{kg}$ (streptomycin) and $1200 \mu \mathrm{g} / \mathrm{kg}$ (gentamycin) observed by Senyk et al. (1990). For neomycin residues in ewe milk, the detection limit was $2600 \mu \mathrm{g} /$ $\mathrm{kg}$, greater than the 1000 to $2000 \mu \mathrm{g} / \mathrm{kg}$ range obtained by Van Os and Beukers (1980) in cow milk.

When comparing the detection limits calculated for the three aminoglycosides in ewe milk with the EUMRL (Table 3), it was proved that the Delvotest "SP" was unable to detect these levels due to the sensitivity drop of Bacillus stearothermophilus var calidolactis for aminoglycosides. Aurelli et al. (1996) obtained good sensitivity for streptomycin $(125 \mu \mathrm{g} / \mathrm{kg})$, lower than the $200 \mu \mathrm{g} / \mathrm{kg}$ established as EU-MRL, when using Bacillus subtilis ATCC 6633 microorganism.

\section{Macrolides}

The erythromycin detection limit $(830 \mu \mathrm{g} / \mathrm{kg}$, Table 4) in ewe milk is within the range of 400 to $900 \mu \mathrm{g} / \mathrm{kg}$ reported by Van Os and Beukers (1980) in cow milk. The detection limit for erythromycin is very high compared with the EU-MRL ( $40 \mu \mathrm{g} / \mathrm{kg}$ ); it is, therefore, necessary to study other microorganisms, such as Streptococcus salivarius ssp. thermophilus, which is sensitive to 75 $\mu \mathrm{g} / \mathrm{kg}$ of erythromycin (Honkanen-Buzalski and Reybroeck, 1995).

The tylosin residues in ewe milk must be present at a concentration of $100 \mu \mathrm{g} / \mathrm{kg}$ (Table 4) in order to be detected photometrically by Delvotest "SP". This level coincides with the detection limit reported by Charm and Ruth (1993) in cow milk and is not far from the 50 $\mu \mathrm{g} / \mathrm{kg}$ set out for EU-MRL.

\section{Tetracyclines}

The detection limit of oxytetracycline $(320 \mu \mathrm{g} / \mathrm{kg}$, Table 4) in ewe milk using ELISA plate reader was lower than $400 \mu \mathrm{g} / \mathrm{kg}$ (Zaadhof et al., 1997) and $500 \mu \mathrm{g} / \mathrm{kg}$ (Luitz and Suhren, 1996), whereas the detection limit of tetracycline (590 $\mu \mathrm{g} / \mathrm{kg}$, Table 4) was similar to the $600 \mu \mathrm{g} / \mathrm{kg}$ reported by Senyk et al. (1990).

As seen in Table 4, the detection limits of tetracyclines were above the EU-MRL (100 $\mu \mathrm{g} / \mathrm{kg})$. Thus, it would be convenient to enhance the conditions of the method in order to detect values approaching the MRL, or assess the utilization of other microorganisms with greater sensitivity for tetracyclines, such as Bacillus cereus var. mycoides (Suhren and Heeschen, 1993; Nouws et al., 1998).

\section{Other Chemotherapeutics}

The Delvotest "SP" method presents a low sensitivity for detection of chloramphenicol $(12,000 \mu \mathrm{g} / \mathrm{kg})$ and trimethoprim $(290 \mu \mathrm{g} / \mathrm{kg})$ residues in ewe milk (Table 4). However, other authors also reported high chloramphenicol detection limits; Senyk et al. (1990) and Van Os and Beukers (1980) observed ranges in cow milk of 9000 to 21,000 and 8000 to $10,000 \mu \mathrm{g} / \mathrm{kg}$, respectively.

Considering the "zero tolerance" stipulated by the EU for chloramphenicol and the high detection limit calculated by means of the microbial inhibitor tests, Kolosova et al. (2000) assayed the indirect competitive ELISA method which allows detection of $0.08 \mu \mathrm{g} / \mathrm{kg}$ of chloramphenicol in cow milk.

\section{CONCLUSIONS}

The utilization of photometric measurements (ELISA reader) and their subsequent treatment by means of a logistic regression model permit a more exact calculation of the Delvotest "SP" detection limits, providing faster and more objective readings, although it would be advisable to review the criterion used in calculation to obtain results similar to those calculated by visual methods.

For those antimicrobial drugs whose detection limits were similar to those set out as EU-MRL, the following values were obtained ( $\mu \mathrm{g} / \mathrm{kg}): 3$, amoxycillin; 2 , ampicillin; 18, cloxacillin; 1 , penicillin "G;" 40, cephalexin; 20, cefoperazone; 33, Ceftiofur; 100, tylosin; 88, sulfadiazine; 44, sulfamethoxazole; 140, sulfametoxypyridazine, and 48 , sulfaquinoxaline. 
The Delvotest method is an economic test, easy to use, and with good detection limits for a wide range of beta-lactam antibiotic, sulphonamide, and tylosin residuals in ewe milk.

In contrast, the Delvotest "SP" method did not detect streptomycin, gentamycin, neomycin, erythromycin, oxytetracycline, tetracycline, chloramphenicol, and trimethoprim at EU-MRL. For this reason, we would recommend improvement in the sensitivity of Delvotest "SP" in order to detect a greater number of residues of veterinary medicines that may be present in ewe milk.

\section{ACKNOWLEDGMENTS}

The authors are grateful to DSM Food Specialties, Dairy Ingredients (Delft, The Netherlands) for their support. Moreover, the authors thank the Polytechnic University of Valencia (Spain) for funding the collaboration of Rafael Althaus with the Department of Animal Science. English translation and text revision by N. Macowan.

\section{REFERENCES}

Althaus, R. L. 1999. Estudio sobre los métodos de detección de inhibidores en leche de oveja de raza Manchega. Ph.D. Diss. Universidad Politécnica de Valencia, Valencia, Spain.

Althaus, R. L., P. Molina, M. Rodriguez, and N. Fernandez. 2001. Evaluation of the BRT ${ }^{\circledR}$ method for detection of $\beta$-lactam antibiotics in ewe milk. Milchwissenschaft 56:568-572.

Aurelli, P., A. Ferrini, and V. Mannoni. 1996. Presumptive identification of sulphonamide and antibiotic residue in milk by microbial inhibitor test. J. Food Control 7:165-168.

Brady, M. S., and S. E. Katz. 1988. Antibiotic/antimicrobial residues in milk. J. Food Prot. 51:8-11.

Carlsson, A., and L. Björck. 1987. The effect of some indigenous antibacterial factors in milk on the growth of Bacillus stearothermophilus var. calidolactis. Milchwissenschaft 42:283-285.

Charm, S. E., and G. P. Ruth. 1993. Advances in charm technology for antimicrobial residues in milk. Pages: 32-46. In Inhibitory Substances in Milk-Current Analytical Practice. IDF Bull. No. 283. International Dairy Federation, Brussels, Belgium.

Cullor, J. S. 1992. Tests for identifying antibiotic residues in milk: How well do they work? Vet. Med. 87:1235-1241.

Currie, D., L. Lynas, G. Kennedy, and J. McCaughey. 1998. Evaluation of modified EC four-plate method to detect antimicrobial drugs. Food Addit. Contam. 15:651-660.

Dewdney, J. M., L. Maes, J. P. Raynaud, F. Blanc, J. P. Scheid, T. Jackson, S. Lens, and C. Verschueren. 1991. Risk assessment of antibiotic residues of beta-lactams and macrolides in foodproducts with regard to their immunoallergic potential. Food Chem. Toxicol. 29:477-483.

Gardner, I. A., J. S. Cullor, F. D. Galey, W. Sischo, M. Salman, B. Slenning, H. Erb, and J. W. Tyler. 1996. Alternatives for validation of diagnostic assays used to detect antibiotic residues in milk. JAVMA 209:46-52.
Honkanen-Buzalski, T., and W. Reybroeck. 1995. Antimicrobials. Pages: 26-35. In Residues of antimicrobial drugs and other inhibitors in milk. IDF Special Issue No. 9505. International Dairy Federation, Brussels, Belgium.

International Dairy Federation. 1991. Detection and confirmation of inhibitors in milk and milk products. IDF. Bull. No. 258. International Dairy Federation, Brussels, Belgium.

International Dairy Federation. 1999. Guidance for the standardized evaluation of microbial inhibitor test. IDF Standard No. 183. International Dairy Federation, Brussels, Belgium.

Katz, S. E. 1982. Report on antibiotics. J. AOAC 65:358-359.

Kelley, W. N. 1982. Qualitative ampule and multitest for beta-lactam residues in fluid milk products: collaborative study. J. AOAC 65:1193-1207.

Kolosova, A. Y., J. V. Samsonova, and A. M. Egorov. 2000. Competitive ELISA of chloramphenicol: influence of immunoreagent structure and application of the method for the inspection of food of animal origin. Food Agr. Immunol. 12:115-125.

Luitz, M., and G. Suhren. 1995. Advanges of protometric evaluation of microbial inhibitor test. Pages 177-181. In Residues of antimicrobials drugs and other inhibitors in milk. IDF Special Issue No. 9505. International Dairy Federation, Brussels, Belgium.

Luitz, M., and G. Suhren. 1996. Nachweis von tetracyclinen in milch mit verschienedenen modifikationen des Brillant-schwarzreduktionsteststs und dem Delvotest SP. DMZ, Lebensmittelindustrie und Milchwissenschaft 117:1010-1015.

Luitz, M., G. Suhren, and W. Heeschen. 1996. Interactions of antimicrobials in milk-Consequences for the detection by a microbial inhibitor test. Milchwissenschaft 51:390-392.

Mourot, D., and S. Loussourorn. 1981. Sensibilité des ferments lactiques aux antibiotics utilisés en médecine vétérinaire. Rec. Med. Vét. 157:175-177.

Nouws, J., G. Loeffen, J. Schouten, H. Egmond, H. Keukens, and H. Stegeman. 1998. Testing of raw milk for tetracycline residues. J. Dairy Sci. 81:2341-2345.

Reichmuth, J., G. Suhren, and R. Beukers. 1997. Evaluation of microbial inhibitor test-the IDF approach. Milchwissenschaft 52:691-695.

SAS $^{\circledR}$ Institute, Inc. 1998. SAS Users guide: statistics version 6.12. Cary, NC.

Schiffmann, A. P. 1992. Methodische und rechtliche probleme beim nachweis von hemmstoffen in milch. Thesis Med. Vet. Diss. University Hannover, Hannover, Germany.

Senyk, G. F., J. H. Davidson, J. M. Brown, E. R. Hallstead, and J. W. Sherbon. 1990. Comparison of rapid test used to detect antibiotic in milk. J. Food Prot. 53:158-164.

Suhren, G., and W. Heeschen. 1993. Detection of tetracyclines in milk by Bacillus cereus microlitre test with indicator. Milchwissenschaft 48:259-263.

Suhren, G., and M. Luitz. 1995. Evaluation of microbial inhibitor tests with indicator in microtitre plates by photometric measurements. Milchwissenschaft 50:467-470.

Suhren, G., and J. Reichmuth. 1998. Nachweis von $\beta$-laktamantibiotikarückstäsden in milk_Erfahrungen mit dem SNAP-Beta-Laktamtest. D.M.Z. Lebensmittelindustrie und Milchwissenschaft 119:674-681.

Van Os, J. L., and R. Beukers. 1980. A multitest system for detection of antibiotics in milk. J. Food Prot. 43:510-511.

Zaadhof, H. J., E. Mältlbauer, A. Vormeiter, and L. Schweizer. 1997. Zur eignung kommerzieller mikrobiologischer hemmstofftests als suchverfahren auf das vorhandensein von antiinfektiva in milch und erzeugnissen auf milchbasis. Archiv für Lebensmittelhygiene $48: 132-144$ 